\title{
Analyses on the Credit Enhancement of BOT Project Finance
}

\author{
Zhi-Ying ZHANG ${ }^{1, a,{ }^{,}}$, Jing TENG ${ }^{1, b}$, Qin FU ${ }^{1, c}$, Wan-Ling ZOU ${ }^{1, d}$ \\ ${ }^{1} \mathrm{XHU}$ University of Architecture and Civil Engineering, Chengdu, Sichuan, China \\ az495603868zy@163.com, b270680846@qq.com, c995928525@qq.com, d12746404228@qq.com \\ ${ }^{*}$ Corresponding author
}

Keywords: Project financing, Credit enhancement, Project company, External credit guarantee.

\begin{abstract}
BOT project financing, as a way to introduce social capital to address the funding gap in the government infrastructure construction, has gained more attention from investors as the financing demands gradually increase. This paper will discuss credit enhancement of BOT project financing from two stages-project company and external credit guarantee, with the aim to provide a reference for establishing the credit system of project financing.
\end{abstract}

\section{Introduction}

In the financing of infrastructure, many trials have been adopted, ranging from the traditional government-funded financing to the current social-capital-funded one which is especially typical of the project financing. Among those trials, BOT project financing is the most frequently applied. In the history of project financing over the past three decades, many large infrastructures like Shajiao B fossil-fuel power plant in Shenzhen have successfully made BOT financing, accumulating a lot of experience for its development. On one hand, the BOT project financing, with its multi-stages, and multi-subjects, has complicated risks of financing and a relatively long payback period for its investment, which has direct influence on its investment income. On the other hand, BOT project financing, based on the future cash flow, is a credit product because its investors are faced with such risks of asymmetric information as adverse selection and moral hazard. In addition, with the increasing pressure of project financing brought by the urbanization and its frustrating examples such as the failure of India's Dabhol Power Company, such kind of financing has witnessed the decreasing efficiency and more difficulties. Once there's a lack of credit, the intensity of project financing will be hard to achieve. So, it is an inevitable trend that the urban infrastructure financing was traditionally funded by the government, social capital (typically with project financing), and then credit funds (here it mainly refers to credit-based project financing). So it is imperative to establish a credit system for BOT project financing.

\section{First stage of credit enhancement—project company}

The traditional way of introducing social capital to infrastructure construction is conducted by a company, as the initiator, which capitalizes on its credit, including assets and liabilities, profits as well as cash flows. The financial condition of the initiator will have direct influence on the financing credit. However, the initiator's credit is often decided by the previous managements, and using the newly-introduced cash flow to make up for previous financial problems will decrease the financing credit. In the financing phase of infrastructure, the internal subjects involved in the BOT project financing mainly consist of: the government, initiator, project company; the external subjects include: credit guarantor and investor. The first stage of credit enhancement is: based on the government's concession agreement on the infrastructure construction and operation, initiator (or the government) will become the shareholder of a project company, and then conduct BOT project financing in the name of the project company. 


\section{Functions of the project company}

The functions of the project company are mainly to isolate bad assets. After the founding of the project company, the capital source to guarantee the payment of loan is restrained in the project's economic intensity of the project company. The initiator is subordinate to the project company, but the latter is not entitled to dispose and manage the project company's assets in accordance with corporation law. For the BOT project initiator, such deteriorating financial factors as the bad bond and loans in its previous operations can be effectively avoided, and these factors' impact on the credit of the new project will be eliminated, thus providing a sound financial environment for the future operation.

\section{Credit enhancement system of the project company}

To conduct the first-stage credit enhancement of BOT project financing calls for the establishment of a project company to effectively coordinate and operate its credit assets. This paper will analyze this from such four aspects as the future economic intensity, equity capital of initiators, franchise rights and the guarantee of the project company.

Future economic intensity. Future economic intensity of a project is the most important credit asset of a company, and the infrastructure BOT project is based on its future income, as a mortgage to get financing. At present, the measurement of future economic intensity is accomplished by economic indicators obtained from the analysis of the cash flow, by the review of such major technical economic factors as the management, technology, labor, raw material, energy, market, macro-economic environment and environmental protection, by the effective control of infrastructure cost, operation cost so as to ensure the stability of cash flow and the feasibility of economic indicators. Therefore, the stability of project's future cash flow holds key to the financing credit.

Equity capital of initiators. The equity capital of initiator is the capital for the establishment of a project company, the limited recourse of BOT project demands that the initiator will use the equity capital as major compensation for default or project failure. Meanwhile, the equity capital, as the credit assets of the project company, demonstrates initiator's confidence in the future economic benefits. Therefore, the clear method of equity capital recourse will increase the credit of BOT project financing to some degree.

Franchise rights. Franchise right is an intangible assets for a project company which is achieved through franchise agreement. On one hand, the concession agreement guarantees that the project company is entitled to domain and manage the project assets; on the other hand, given the fact that the BOT project company has limited capital, the government will provide in the franchise agreement with some credit guarantee such as preferential policies on land and tax, an certain number of product purchase agreements, and not undermine the feasible base of project (the government will not confer to build or operate other projects that will compete with this one) [1].

Guarantee of the project company. The guarantee of a project company mainly embodies in two aspects. One is the enterprise sponsor (or the initiator and project contractor jointly) guarantees on the completion risk of the project company's proposed project. Once such problems as project delay or cost overruns occur, the project initiator, in accordance with its obligation on completion guarantee, may add to equity capital, or the investors may withdraw funds from the standby letters of credit established by a designated bank. The other is the floating charge for the future assets created by the project company, and investors are entitled to preferentially dispose assets when the project company defaults or gets bankrupted. The project company's guarantee, as its credit commitment, can lower the risks for investors and carry out more debt [2].

However, since the BOT project financing is based on the project's future economic intensity and the government, initiator as well as project company share common interests (shown in Fig. 1), the risks of asymmetric information, mainly the "adverse selection" and "moral hazard" facing the two parties will appear as the contractual relationship between the project company and investors starts. 


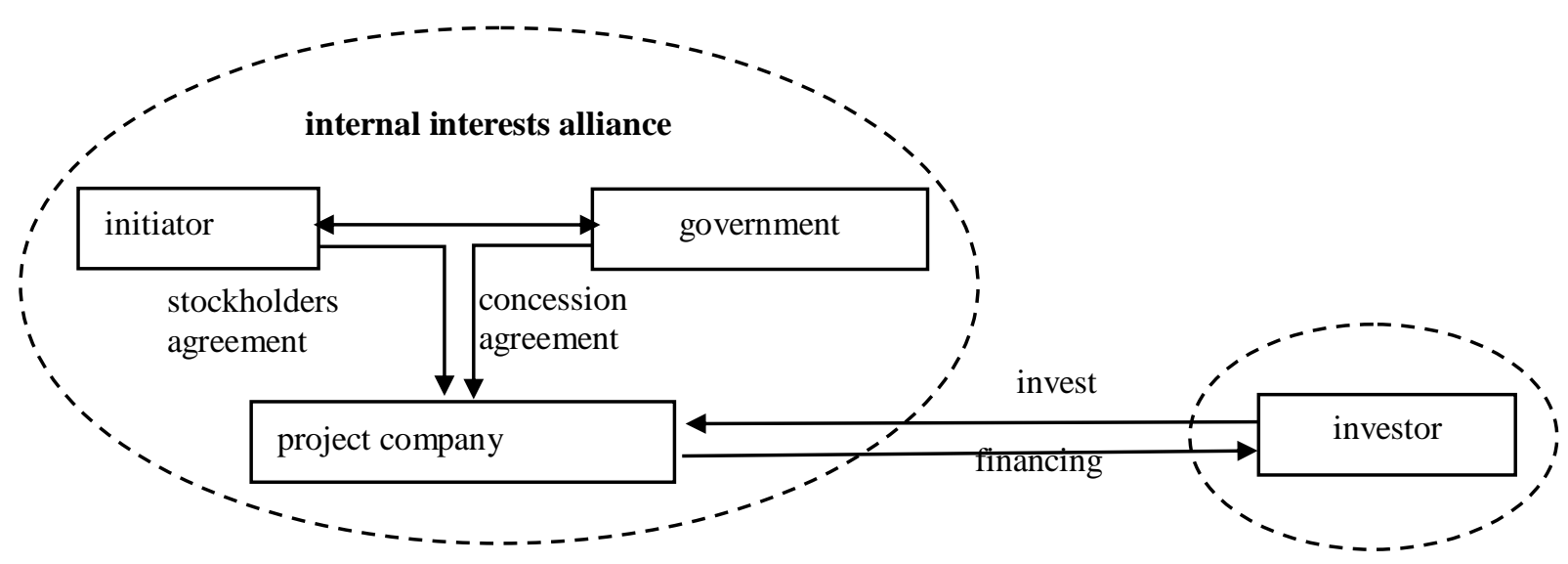

Fig. 1 Interest relationship of financing entities

"Adverse selection" refers to such case in which the project company hides the information of those low-profitability projects and claims itself to be highly-profitable, and as a result, the investors are unable to judge about the authenticity of the information given by the project company, and can only decide whether to invest in and the investment amount according to expected prices in the market. When the investors find that the projects they invest in cannot live up to their expectations, they will lower the prediction of profitability of the project and the investment price. At this time, while the highly-profitable projects with large costs will be expelled out of the market due to its failure in the competition, the less profitable projects can stay in the market, which will break the competition rules of the market and dysfunction the market. "Moral hazard" means that the success of a project is heavily dependent on the operation capacity and professional ethics of the project company. After financing, these two factors are unknown to the investors, thus providing the project company with opportunism of conducting embezzlement of funds or dereliction of duty which will bring losses to the investors. Therefore, the second stage in the BOT project credit enhancement - the third-party guarantee come into being[3].

\section{Second stage of credit enhancement — external credit guarantee}

In the BOT project financing, there are internal subject guarantee and external subject credit guarantee in accordance with different subjects. In the first stage of credit enhancement, the credit guarantee and the guarantee of the project company given by the government, are in essence the internal subject guarantee of BOT project financing. Apart from that, since the internal subjects, represented by the project company, share common interests (so in this stage, it is presumed that the project company can represent the internal subject group), the realization of investors' limited recourse in the BOT project financing and the insurance of its interests call for credit guarantee from the external agencies.

\section{Analyses on the expanding of financing amount with the introduction of external credit guarantee}

Due to the project company's lack of credit, and asymmetric information, it is still difficult for the investors to accurately examine the risk status of the project company even there are only the project company and external credit guarantee agencies involved. In addition, one feature of investors in their investment is to ensure the safety of the capital. Therefore, investors tend to refuse such kind of project for the sake of capital safety. But the external credit guarantee agencies, as new financial service agency, can be very effective in resolving the ration problem between them through credit enhancement.

In the basic model of credit capital between the project company and investors, the curve $D$ represents financing demand of project company, and the curve $S$ stands for fund supply of investors. Since there is still risk of adverse selection when the lending rate is relatively high, curve $S$ will first rise and then fall as the rate climbs. The investment amount that investors can give to the 
project company is directly linked with various credit terms of the project company, and in fact, there are not enough financing demands that can satisfy the conditions, so this paper will use curve $D^{\prime}$ to represent qualified financing demands. The equilibrium point of project company and external credit guarantee agencies is point $\left(D_{1}^{*}, S_{1}^{*}\right) \cdot S_{1} *$ stands for the investment amount investors can give to project company in accordance with credit conditions, $R_{1}{ }^{*}$ is equilibrium yield rate, $D_{1}$ is the whole capital demand of project company, so the unachieved financing demand of the project company $X_{1}=D_{1-} D_{1} *$. The credit capital equilibrium between the project company and investors is shown in Fig. 2.

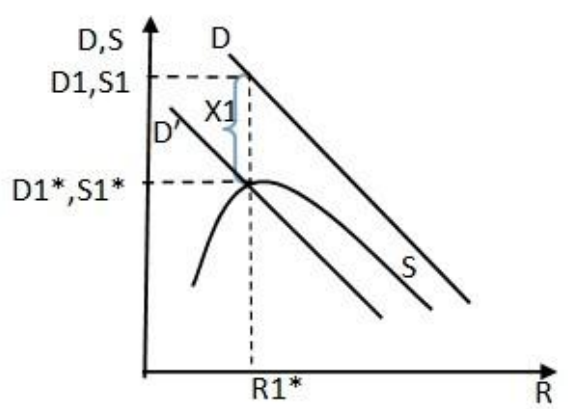

Fig. 2 Credit equilibrium of two sides

In the basic model of credit capital among project company, investors and external credit guarantee agencies, with the participation of external credit guarantee agencies, project company's financing cost, that is the capital demand will increase on one part, so curve $D^{\prime}$ will move to $D^{\prime \prime}$; on the other part, financing credit of project company will be enhanced. The external credit guarantee agencies will provide guarantee for project company, and promise to share a certain portion of responsibilities of default compensation. This will reduce investors' risks in investment to a large extent, make the capital safer, so curve $S$ will move to $S^{\prime}$. At this time, the equilibrium point of the three parties is point $\left(D_{2} *, S_{2} *\right)$, equilibrium capital demand is $S_{2} * . R_{2} *$ is the equilibrium yield rate, $D_{2} *$ is the financing capital of project company, so the unachieved financing demand $X_{2}=D_{1}-D_{2} *$. The credit capital equilibrium among project company, investors and external credit guarantee agencies is Shown in Fig. 3.

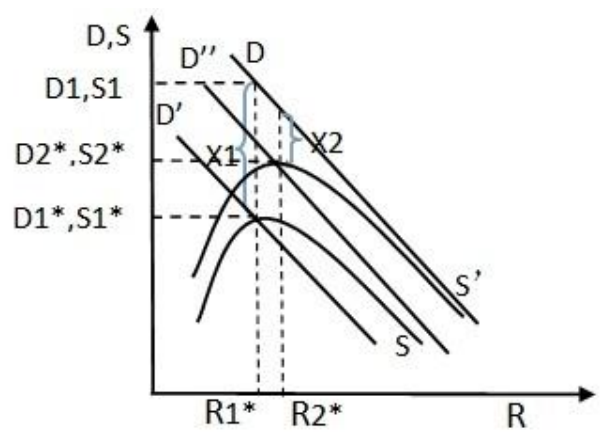

Fig. 3 Credit equilibrium of three sides

Based on the analyses on the basic model of credit capital, the financing efficiency has been enhanced due to the assistance of external credit guarantee agencies, which manifests as: the obvious increase in the investors' investment and in the financing demands of the project company that have been satisfied $\left(D_{2^{*}}>D_{1}^{*}\right)$, and the evident decrease in the unsatisfied financing demands of the project company $\left(X_{2}<X_{1}\right)$.therefore, the existence of credit guarantee agencies has dramatically increased the financing amount of BOT project. 


\section{Analyses on the types and adaptability of external credit guarantee}

The external guarantee mainly consists of credit guarantee provided by such financial institutions as banks, bonding companies, reliable trust institutions and insurance companies. The trust institutions mainly provide credit guarantee to the securitization of project assets; the bonding companies, subject to restrictions of business lines, may easily lead to the damage of the vigor of credit enhancement; the banks mostly adopt performance guarantee or closed account to serve as the basic support of debt repayment, and the insurance companies can transfer various risks (including force majeure ) in the building and operation processes of BOT project through a insurance plan, therefore, the external credit guarantee jointly operated by banks and insurance companies are frequently adopted in BOT project financing[4].

\section{Conclusion}

Based on the above analyses, to realize the credit enhancement of BOT project financing, the various subjects need to corporate with each other. The project company need to take the base of BOT project financing - credit assets, the government and initiators need to actively cooperate and negotiate, appropriately make the allocation of credit assets into project company and the economic intensity of project itself, and increase the internal credit of BOT project financing. From the outside perspective, the credit guarantee institution, as the second stage in the credit enhancement of financing, its structural design will have essential impact on the increase of efficiency in the BOT project financing and the credit augment.

\section{Acknowledgements}

This paper is financially supported by the Innovation Foundation of Graduate student of Xihua University(ycjj2014091), Science and Techonlogy Innovation Project Foundation of Housing and Urben-rural development(2013-R1-4), Key Laboratory Research Fundation Project of Sichuan University(szjj2012-033). Thanks to my university - Xihua University, the careful guidance of my tutor- Yong Xiang. I will keep paith.

\section{References}

[1] Linli Han: Credit of Government in the Financing of Project BOT, Journal of Shanghai University of Finance and Economics.Vo1.5, No.3(2003), p. 46-47. in china.

[2] Yong Zhu: Project Financing and Credit Enhancement Technology Case Studies. Business Research. Vol. 8 (2005), p. 128. in china.

[3] Keliu Zhu, Hou Haiqing: Analysis of Asymmetric Information Risk in the Project Finance. Journal of Xi'an University of Petroleum. Vol. 15 (2006), p. 27. in china.

[4] Tianlin Liang: Defects of Legal System of B0T Project Financing Guarantee and Suggestions for Improvement. Journal of Hunan Economic Management College. Vol. 17 (2006), p. 84. in china. 